\title{
Powder for Injectable Suspension Dosage
} Form

National Cancer Institute

\section{Source}

National Cancer Institute. Powder for Injectable Suspension Dosage Form. NCI

Thesaurus. Code C42976.

A powder intended for injection following reconstitution to form a suspension. 